\title{
Intensity of leaf spot and rough bark diseases in cinnamon accessions collected from major cinnamon growing areas of Sri Lanka
}

\author{
Rumana Azad', K.L. Wasantha Kumara ${ }^{2}$, Gamini Senanayake², R.A.A.K. Ranawaka ${ }^{3}$, D.K.N.G. \\ Pushpakumara $^{4}$ and Sudarshanee Geekiyanage ${ }^{2 *}$ \\ ${ }^{l}$ Board of Study in Agriculture, Faculty of Graduate Studies, University of Ruhuna, Matara. \\ ${ }^{2}$ Department of Agricultural Biology, Faculty of Agriculture, University of Ruhuna, Mapalana, Kamburupitiya. \\ ${ }^{3}$ Mid Country Research Station, Department of Export Agriculture, 1095, Sirimavo Bandaranayake Mawatha, Peradeniya. \\ ${ }^{4}$ Department of Crop Science, Faculty of Agriculture, University of Peradeniya, Peradeniya.
}

Submitted: 15 July 2018; Revised: 21 February 2019; Accepted: 06 May 2019

\begin{abstract}
Leaf spot and rough bark diseases are of high concern among cinnamon growers in Sri Lanka due to potential yield losses. Comprehensive information on distribution and intensity of the above diseases is not available in Sri Lanka. During this study, disease assessment keys were developed for leaf spot and rough bark diseases with subjective scales, which could be useful in assessing the severity of the two diseases. Two hundred and eighty cinnamon accessions from major cinnamon growing areas of Matara, Galle, Kalutara, Kurunegala, Ratnapura and Humbantota Districts were used to determine the intensities of the above diseases. All the districts showed a high level of leaf spot disease severity, where $23.81 \%$ accessions from Galle and $17.14 \%$ accessions from Kalutara districts exhibited the leaf spot disease severity scale of 6. Moreover, $60 \%$ accessions from Kurunegala and $45.71 \%$ accessions from Kalutara districts showed the leaf spot disease severity scale of 5. According to the study on rough bark disease severity, none of the major cinnamon growing areas is at a high risk of rough bark disease. However, the present study indicates the initiation and progression of rough bark disease in the six districts, where Matara district showed considerable levels of infection having $17.39 \%, 11.59 \%, 5.80 \%$ and $4.35 \%$ of accessions with disease severity scales 2, 3, 4 and 5, respectively. The estimates of the two disease severities explain the present scenario of extent of the two diseases across major cinnamon growing areas in the country.
\end{abstract}

Keywords: Cinnamomum verum, cluster analysis, leaf spot disease severity, rough bark disease severity.

\section{INTRODUCTION}

The genus Cinnamomum (Family: Lauraceae) consists of about 250 species, grown in Asia and South and Central America mainly, and in Australia to some extent (Mabberley, 2008). There are nine Cinnamomum species found in Sri Lanka, among which Cinnamomum verum is considered as the most important species, contributing to $70 \%$ of the world's true cinnamon bark production (Abeysinghe et al., 2009). The export volume and export earning of cinnamon in the year 2016 were 14,692.8 metric tons and 23177.9 million rupees, respectively (Sri Lanka Customs, 2016). Cinnamomum verum has been found in the central hilly areas of Sri Lanka and also in Sinharaja and Knuckles forest reserves. The Wet Zone of Sri Lanka is highly favourable for cinnamon cultivation. Commercial cinnamon cultivation is also carried out along the coastal belts of Kalutara, Galle and Hambantota at an elevation of about $250 \mathrm{~m}$ above the mean sea level (Department of Export Agriculture, 2013).

Leaf spot disease of cinnamon is caused by Colletotrichum gloeosporoides (Penz.) Penz. \& Sacc. (Karunakaran \& Nair, 1980; Kumara, 1999; Anandaraj \& Devashayam, 2004). Incidences of leaf spot disease

\footnotetext{
*Corresponding author (sudarshanee@agbio.ruh.ac.lk; (iD https://orcid.org/0000-0002-3771-2680)
} 
are reported from all cinnamon growing areas of Sri Lanka. Young seedlings show small brown specks on leaf lamina, which later coalesce forming irregular patches. In older leaves, these small specks coalesce and form necrotic blotches (Anandaraj \& Devasahayam, 2004). The fungal pathogen Colletotrichum capsici has been recorded causing red leaf spot of cinnamon in the lower Pulney Hills of Tamil Nadu (Prakasam, 1991). In Taiwan, infection of leaves and twigs by Colletotrichum gloeosporoides (Penz.) Penz. \& Sacc. had been reported (Fu \& Chang, 1999). According to Kumara (1999), 18 $\%$ foliar damage had been recorded due to the leaf spot disease in Matara, Sri Lanka. However, there are no records on a correlation between cinnamon yield and the leaf spot disease severity.

Rough bark disease has been reported in cinnamon, which turned out to be a great concern among the growers in Sri Lanka in the recent past. The disease symptoms appear as black or brown spots with borders on the stem, which later develop into large patches and produce the scab-like appearance. Inter-veinal chlorosis of young leaves is common in affected plants. Finally, the affected young shoots die causing heavy yield losses (Rajapakse \& Kumara, 2007). Although an investigation on the causal organism of rough bark disease of cinnamon showed that a fungal pathogen similar to Phomopsis sp. is responsible for disease incidence, it was not confirmed to species level (Jayasinghe et al., 2017).

A number of studies indicated that there was a variation in disease severities due to environment, genotype or environment and genotype interactions in plants. A variation was reported in anthracnose disease caused by $C$. gloeosporoides at 31 sites in Queensland (Davis et al., 1984). Geographical and temporal distribution of hosts is closely connected with the differences in pathogenicity and distribution of fungal pathogens (Guillaumin et al., 1993; Ristaino \& Gumpertz, 2000). Climate change also affects the crop and pathogen interaction (Burdon, 1987). Sri Lankan cinnamon accessions exhibit a wide variation in morphology including leaf and flower characters, which may reflect the genetic diversity (Azad et al., 2016; 2018). Leaf morphology of cinnamon has been suggested as a morphological marker for essential oil composition (Wijesinghe \& Gunarathna, 2001) and for genetic analysis (Azad et al., 2015). The correlation between leaf morphology and disease severity was tested during this study, which would be useful in the identification of resistant genotypes for breeding programmes.

Assessment of geographical distribution of leaf spot disease and rough bark disease is important in disease

management and breeding. According to the best of our knowledge, this is the first attempt on assessing the intensity of leaf spot and rough bark diseases through disease assessment keys in major cinnamon growing areas of Sri Lanka.

Thus, the present study was conducted with the objectives of: development of disease assessment keys; determination of leaf spot and rough bark disease intensities using disease assessment keys in cinnamon accessions collected from major cinnamon growing areas of Sri Lanka; and determination of the correlation between leaf spot and rough bark disease severities with leaf morphology of cinnamon accessions.

\section{METHODOLOGY}

\section{Study site}

A field survey was carried out to determine the incidences of leaf spot disease and rough bark disease (Figure 1). More than 30 year old cultivations of 51 cinnamon lands from Matara, Galle, Kalutara, Kurunegala, Ratnapura and Hambantota Districts were used for the field survey during June 2014 to April 2015 (Figure 2). The lands for field data collection were selected with the help of the database of the Department of Export Agriculture (Table 1). Two hundred and eighty accessions from the above 51 lands in the six districts were used for the survey. The apparently distinct accessions of leaf morphology were randomly selected among total accessions keeping $5-8 \mathrm{~m}$ distance between two selected accessions in each land. The leaf morphology was recorded following the Descriptors for cinnamon (Cinnamomum verum) (Team of TURIS 2013 Project, 2016).

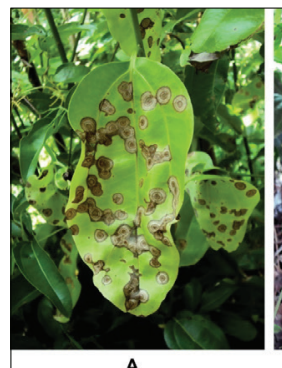

A

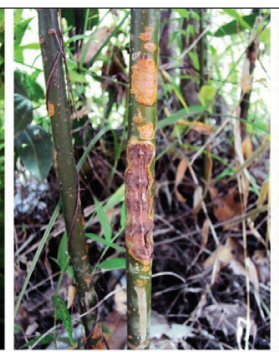

B

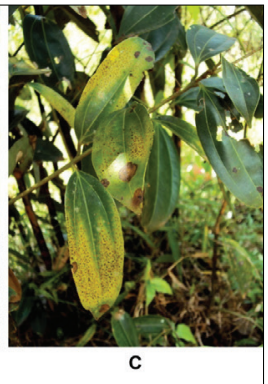

Figure 1: Diseased Cinnamomum verum specimens from field survey. A: cinnamon leaves affected by leaf spot disease; B: cinnamon stem affected by rough bark disease; C: leaf chlorosis of a cinnamon plant affected by rough bark disease 


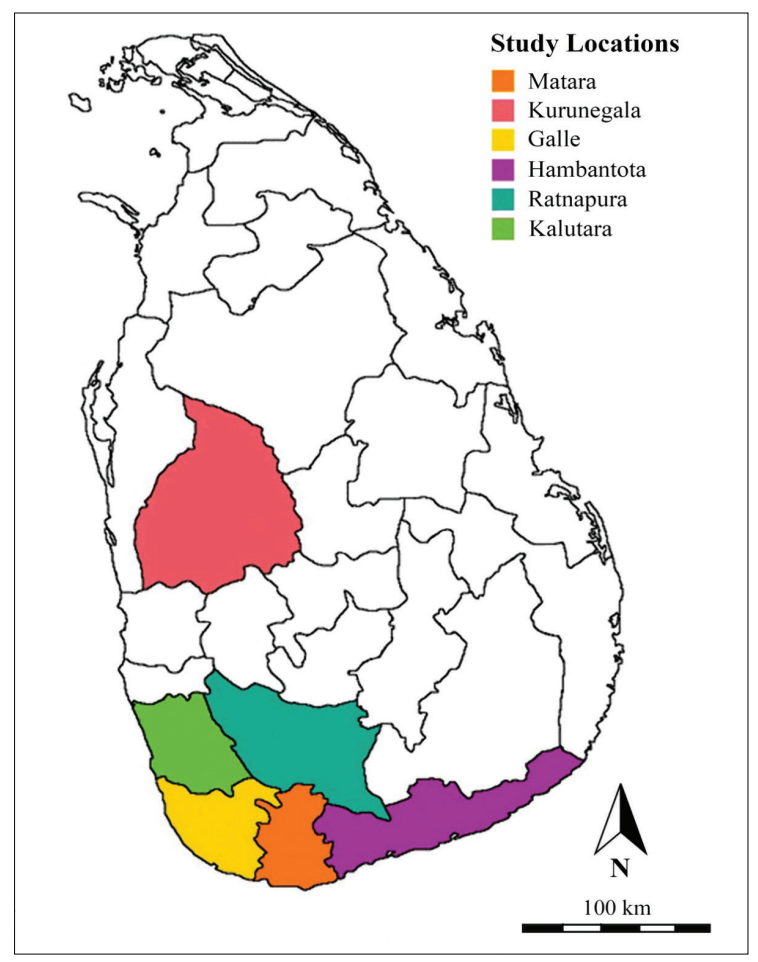

Figure 2: Map of Sri Lanka showing study locations of leaf spot and rough bark diseases of cinnamon

Source: FAO Fishery Country Profile - Sri Lanka (http://wwwfao.org/f/oldsite/FCP/en/LKA/profile.htm)

\section{Development of cinnamon leaf spot disease assessment key and evaluation of leaf spot disease severity}

A cinnamon leaf spot disease assessment key, which consisted of a $0-9$ subjective scale $(0=$ no infection; $1=$ up to $10 \%$ infection; $2=11-20 \%$ infection; $3=$ $21-30 \%$ infection; $4=31-40 \%$ infection; $5=41-50 \%$ infection; $6=51-60 \%$ infection; $7=61-70 \%$ infection; $8=71-80 \%$ infection; $9=$ more than $81 \%$ infection) was developed based on the percentage of diseased leaf area (Figure 3) using Assess 2.0 $0^{\circledR}$ software (Lamari, 2008) and the range of disease severity. The accessions were identified with the level of leaf spot disease severity (LSDS). During the field survey, five mature leaves were taken randomly from each selected accession, making a total of 1,400 leaves to estimate the disease severity visually using the leaf spot disease assessment key. The percentage of accessions with LSDS from each district was determined to find out the impact of the disease.

\section{Development of cinnamon rough bark disease assessment key and evaluation of rough bark disease severity}

Rough bark disease assessment key (Figure 5) with a $0-7$ subjective scale $(0=$ no infection; $1=$ less than $5 \%$ infection; $2=5-15 \%$ infection; $3=16-30 \%$ infection; $4=31-50 \%$ infection; $5=51-80 \%$ infection;

Table 1: The study locations of 280 cinnamon accessions in the six districts

\begin{tabular}{llcc}
\hline District & Study location & $\begin{array}{c}\text { Number of } \\
\text { fields }\end{array}$ & $\begin{array}{c}\text { Number of } \\
\text { accessions observed }\end{array}$ \\
\hline \multirow{2}{*}{ Matara } & Ehala Athuraliya & 4 & 12 \\
& Karapotu Gala & 3 & 15 \\
& Palolpitiya, Thihagoda & 1 & 5 \\
& Pahalahena, Ehalawitiyala & 1 & 5 \\
& Medagoda, Kamburupitiya & 1 & 10 \\
Galle & Puhulwella, Kirinda, Kamburupitiya & 4 & 22 \\
& Niyagama and Hiyare-east, Akmeemana & 1 & 10 \\
& Thilakapura, Ambalangoda & 3 & 18 \\
Kurunegala & Goduwa, Balapitiya & 3 & 20 \\
Kalutara & Elpitiya & 3 & 18 \\
& Karandeniya & 3 & 18 \\
& Ehhagamua & 1 & 5 \\
\multirow{3}{*}{ Ratnapura } & Mathugama, Agalawatta & 3 & 15 \\
& Horana & 2 & 5 \\
& Embilipitiya & 1 & 17 \\
Hambantota & Hatangala, Weligapola & 4 & 15 \\
& Pallebedda & 2 & 20 \\
& Walasmulla & 4 & 15 \\
& Karamatiya, Walasmulla & 3 & 20 \\
\hline
\end{tabular}


$6=$ more than $80 \%$ infection; $7=$ death due to rough bark disease) was developed considering the percentage of diseased stem area and verifying with the percentage of diseased area by Assess $2.0^{\circledR}$ software (Lamari, 2008). The accessions were identified with the level of rough bark disease severity (RBDS). Thirty centimetres long infected stems were observed randomly to measure the RBDS from each accession at the time of field survey visually, using the rough bark disease assessment key. The percentage of accessions with RBDS from each district was determined to find out the impact of the disease (Figure 6).

\section{Relationship between disease severity and leaf morphology}

Leaf morphological data including leaf length (LL), leaf width (LW), leaf length-width ratio (LLWr) and petiole length (PL) of 280 accessions were recorded at the time of field survey. All accessions were clustered based on the variation of the four morphological characters following Ward's hierarchical clustering method using IBM SPSS Statistics 20.0 software (version 20, IBM, USA). The LSDS and RBDS of the 280 accessions were included according to the above clusters. Correlation coefficients were calculated at $0.01 \%$ probability level using the same software for the relationships of each disease severity and each leaf morphological character. A scatter plot was developed with the LSDS and PL of the accessions belonging to cluster 2 using MINITAB version 14 software (Minitab 14, 2003).

\section{RESULTS AND DISCUSSION}

Leaf spot disease was recorded in all cinnamon growing areas of Sri Lanka during the survey period from June 2014 to April 2015. Almost all districts showed a high level of leaf spot disease occurrence (with an average leaf spot disease severity scale $>4$ ). The average values of LSDS scale in Galle (4.82), Kurunegala (4.6) and Kalutara (4.74) districts were higher than the rest of the districts (Table 2). Sixty percent accessions from Kurunegala and $45.7 \%$ of the accessions from Kalutara districts gave a disease severity scale of 5, while $23.81 \%$ accessions from Galle and $17.14 \%$ accessions from Kalutara districts exhibited a LSDS scale of 6 . Furthermore, $52.2 \%$ accessions from Matara, $40.5 \%$ accessions from Galle, $40.0 \%$ accessions from Kurunegala, $57.7 \%$ accessions from Ratnapura and $51.4 \%$ accessions from Hambantota gave a disease severity scale of 4 (Figure 4).

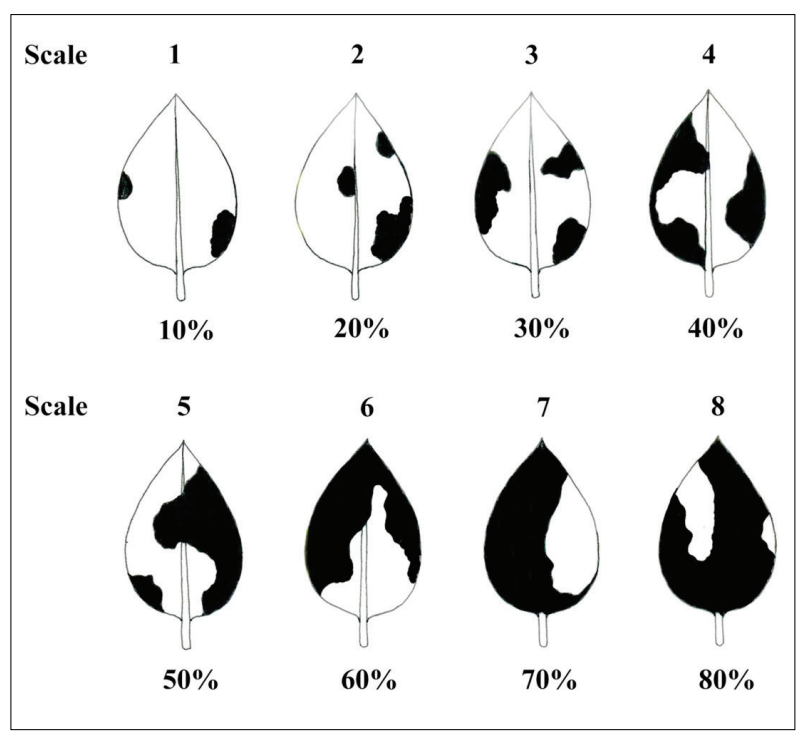

Figure 3: A pictorial diagram of cinnamon leaf spot disease severity assessment key indicating the maximum level of disease severity for each scale. Shades represent the area of diseased tissue given in percentage below each picture

Table 2: Average leaf spot and rough bark disease severities in six districts of Sri Lanka during June 2014 to April 2015

\begin{tabular}{lcc}
\hline District & $\begin{array}{c}\text { Leaf spot } \\
\text { disease severity }\end{array}$ & $\begin{array}{c}\text { Rough bark } \\
\text { disease severity }\end{array}$ \\
\hline Matara & 4.50 & 1.30 \\
Galle & 4.82 & 1.31 \\
Kalutara & 4.74 & 1.29 \\
Kurunegala & 4.60 & 0.40 \\
Ratnapura & 3.65 & 0.96 \\
Hambantota & 3.91 & 0.94 \\
\hline
\end{tabular}

RBDS was recorded following a disease severity assessment key with a scale from $0-7$ in the six districts and presented in Figure 6 . The average values of disease severity in Matara (1.30), Galle (1.31) and Kalutara (1.29) districts were higher than 1 in contrast to the other districts (Table 2). Cinnamon accessions from Kurunegala District were less susceptible to rough bark disease as only $20 \%$ of the accessions gave a disease severity scale of 2 (Figure 6). Only a few accessions (1.92\% from Ratnapura, $2.38 \%$ from Galle, $2.86 \%$ from Kalutara and $2.86 \%$ from Hambantota districts) gave the disease severity level of 6 , which was the highest level recorded among accessions. 

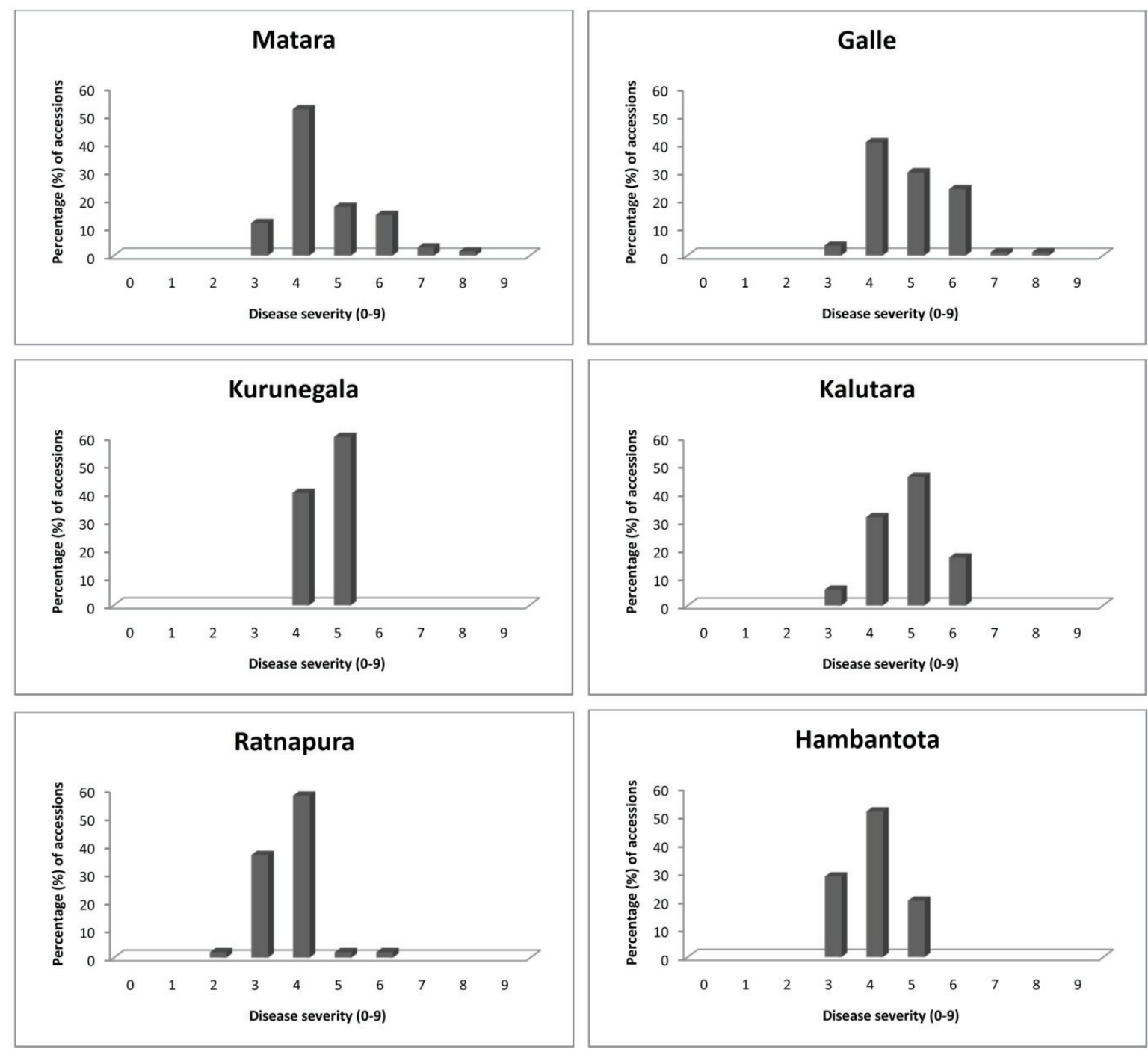

Figure 4: Percentage of accessions showing leaf spot disease severity at $0-9$ scale in major cinnamon growing districts in Sri Lanka during June 2014 to April 2015

Bark is the most valuable part of cinnamon plant. Infections on the bark reduce both the quality and quantity of the yield. Based on the current study, none of the major cinnamon growing areas is at a high risk of rough bark disease. However, the initiation of the rough bark disease in the above six districts is detected. Matara District exhibited a considerable level of infection recording $17.39 \%, 11.59 \%, 5.80 \%$ and $4.35 \%$ accessions with disease severity scales of 2,3 , 4 and 5 , respectively, which could be due to conducive environmental factors such as climatic conditions, type of pathogen prevailing and nature of soil in the area, etc.
Understanding the nature of host-pathogen interaction is of utmost importance in disease management: even the initial level of disease severity can lead to a complete failure of harvest under favourable environmental conditions. In this situation, assessing the rough bark disease in terms of disease incidence instead of disease severity would have been more meaningful. As the identification of causal organism/s of rough bark disease is still not properly executed, measures should be taken to correctly identify the pathogen and to take appropriate control measures to avoid future yield losses of the crop. 


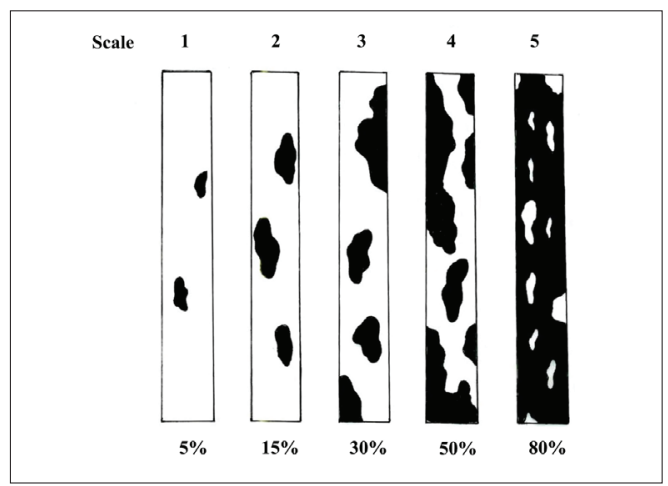

Figure 5: A pictorial diagram of rough bark disease severity assessment key indicating the maximum level of disease severity for each scale. Shades represent the area of diseased tissue given in percentage below each picture.
Cluster analysis using Ward's method classified the 280 cinnamon accessions into seven clusters at a rescaled distance of 2.5 (Figure 7). All data of the LSDS and RBDS of the 280 accessions were rearranged according to cluster-wise accessions. The highest average LSDS index (4.83) and the highest average RBDS index (1.75) were observed in cluster 2 among the seven clusters (Table 3 ). Furthermore, the highest average leaf length $(18.74 \mathrm{~cm})$ and the highest average petiole length $(2.21 \mathrm{~cm})$ were recorded in cluster 2 .

Therefore, correlation coefficient analysis was conducted for each cluster to find out the correlation between disease severities and the respective morphological character. A significant relationship was not found between each disease severity and morphological characters within each cluster except for leaf spot disease severity (LSDS) of accessions of
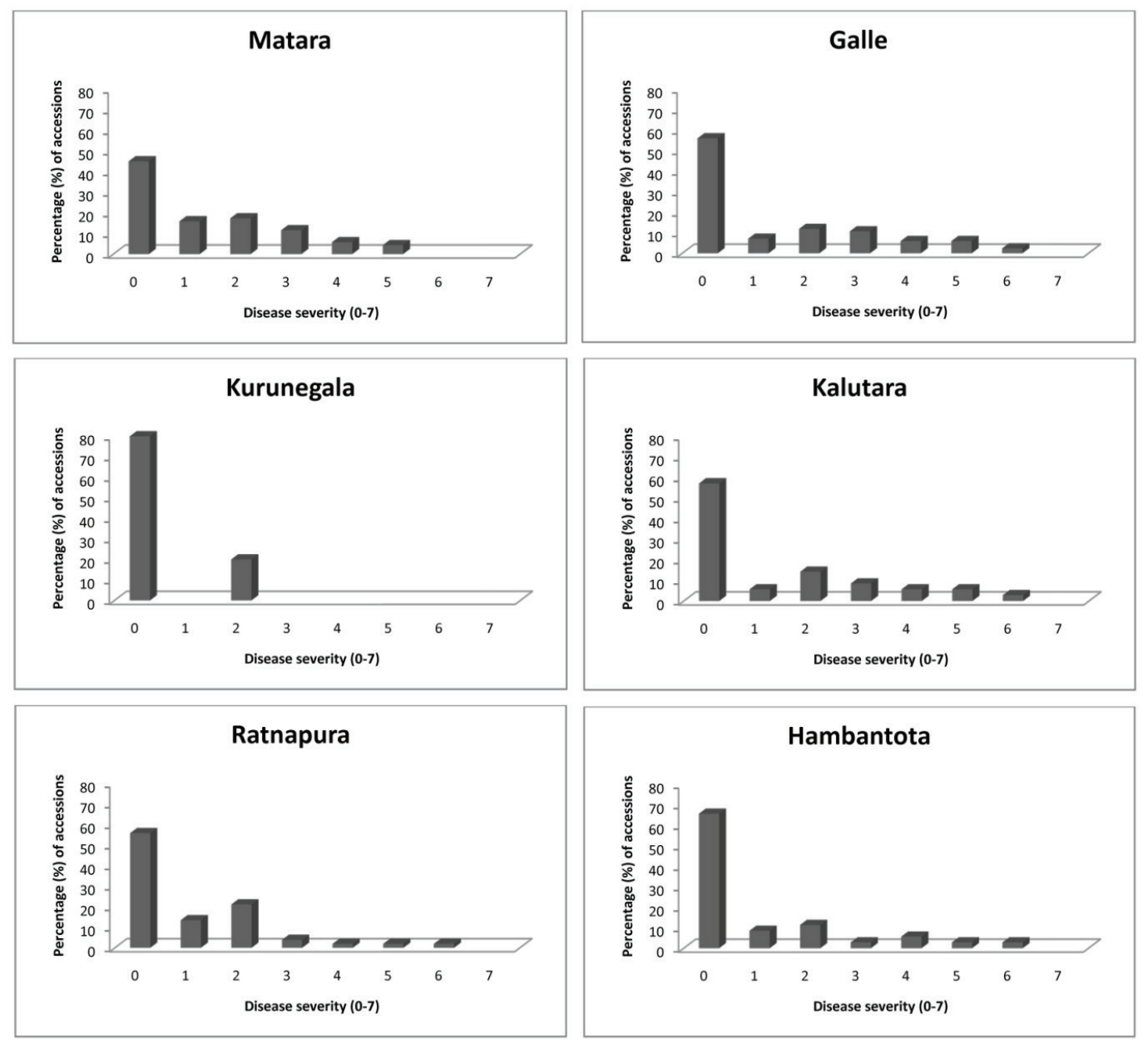

Figure 6: Percentage of accessions showing rough bark disease severity according to $0-7$ scale in major cinnamon growing areas of Sri Lanka 


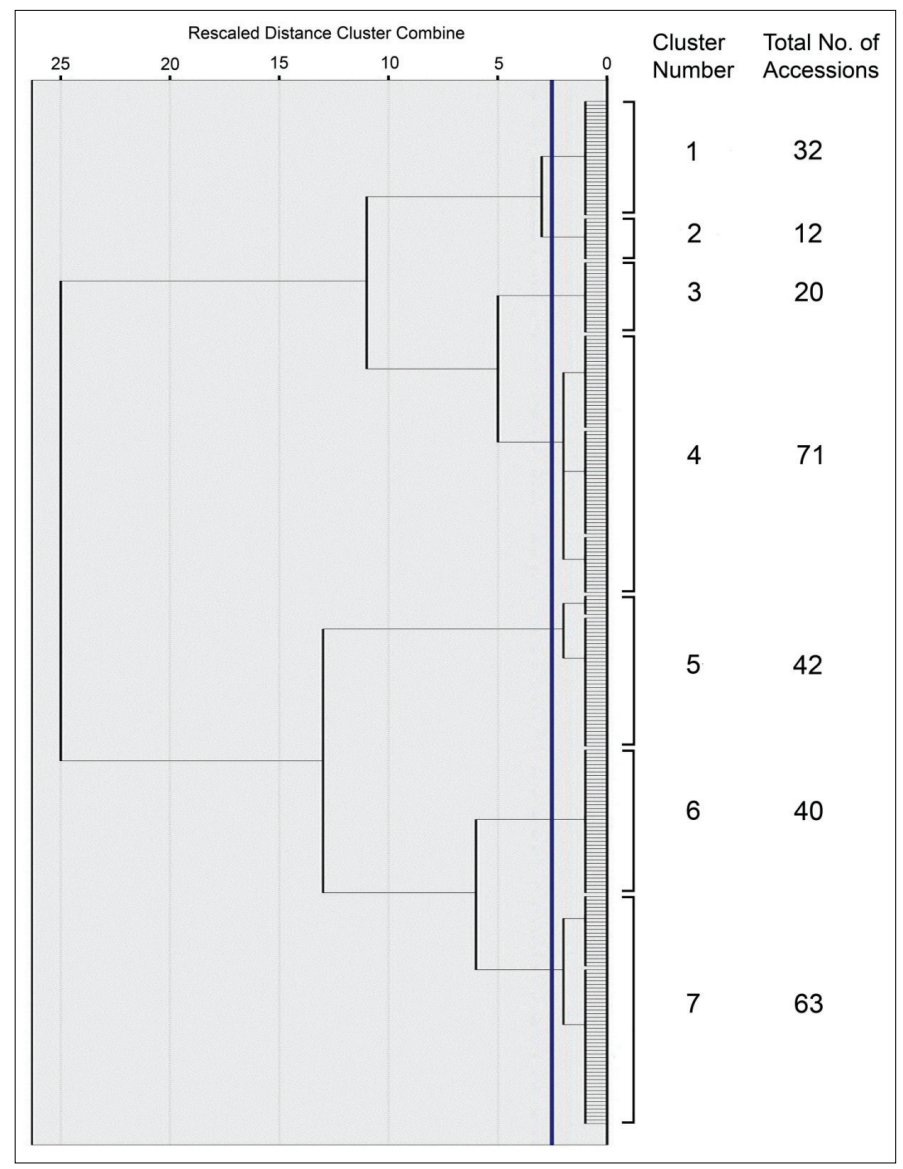

Figure 7: The dendogram of cinnamon accessions derived through Ward's linkage cluster analysis based on four quantitative characters of leaf length, leaf width, leaf length-width ratio and petiole length.

Table 3: Variation of average leaf spot disease and rough bark disease severity indices with selected morphological characters for each cluster of the dendogram derived through Ward's linkage analysis

\begin{tabular}{|c|c|c|c|c|c|c|}
\hline \multirow{2}{*}{$\begin{array}{l}\text { Cluster } \\
\text { number }\end{array}$} & \multicolumn{4}{|c|}{ Average value of morphological character ${ }^{*}$} & \multirow{2}{*}{$\begin{array}{c}\text { Average } \\
\text { LSDS } \\
\text { index }\end{array}$} & \multirow{2}{*}{$\begin{array}{c}\text { Average } \\
\text { RBDS } \\
\text { index }^{* * *}\end{array}$} \\
\hline & $\mathrm{LL}(\mathrm{cm})$ & $\mathrm{LW}(\mathrm{cm})$ & LLWr & PL $(\mathrm{cm})$ & & \\
\hline 1 & 15.96 & 6.68 & 2.39 & 1.95 & 4.47 & 0.88 \\
\hline 2 & 18.74 & 6.97 & 2.71 & 2.21 & 4.83 & 1.75 \\
\hline 3 & 15.81 & 5.47 & 2.89 & 1.80 & 4.25 & 1.3 \\
\hline 4 & 13.21 & 5.28 & 2.51 & 1.56 & 4.32 & 1.01 \\
\hline 5 & 14.38 & 7.54 & 1.91 & 1.87 & 4.60 & 0.95 \\
\hline 6 & 10.50 & 4.97 & 2.12 & 1.26 & 4.18 & 1.30 \\
\hline 7 & 12.92 & 6.14 & 2.10 & 1.57 & 4.41 & 1.44 \\
\hline
\end{tabular}

"LL: leaf length; LW: leaf width; LLWr: leaf length and width ratio; PL: petiole length

** Average LSDS index: average leaf spot disease severity index

${ }^{* * *}$ Average RBDS index: average rough bark disease severity index 
cluster 2 showing positive significant linear relationship with petiole length $(0.773)$ at $0.01 \%$ probability level (Table 4). The absence of correlations between leaf characters and the diseases could be due to phenotypic plasticity of leaf length, leaf width and petiole length of cinnamon under varying environments of different growing districts. Leaf character plasticity in alpine plants is suggested as an important mechanism to tolerate changing environmental conditions (Henn et al., 2018).

Regression analysis was performed between LSDS and PL of accessions belonging to cluster 2 using Minitab 14 software (Figure 8). According to non-linear regression $(\mathrm{R}-\mathrm{Sq}=62 \%)$, there was a relationship between LSDS and PL of the above accessions.
Table 4: The correlations between leaf spot disease severity (LSDS) with leaf length (LL), leaf width (LW), leaf length-width ratio (LLWr) and petiole length (PL) according to Pearson's correlation coefficient evaluated in the cinnamon germplasm collection from cluster- 02

\begin{tabular}{lccccc}
\hline Variable & LSDS & LL & LW & LLWr & PL \\
\hline LSDS & - & -0.058 & 0.161 & -0.263 & $0.773^{* *}$ \\
LL & & - & $0.906^{* *}$ & $-0.748^{* *}$ & 0.102 \\
LW & & & - & $-0.954^{* *}$ & 0.159 \\
LLWr & & & & - & -0.153 \\
PL & & & & & - \\
\hline
\end{tabular}

**. Correlation is significant at the 0.01 level (2-tailed).

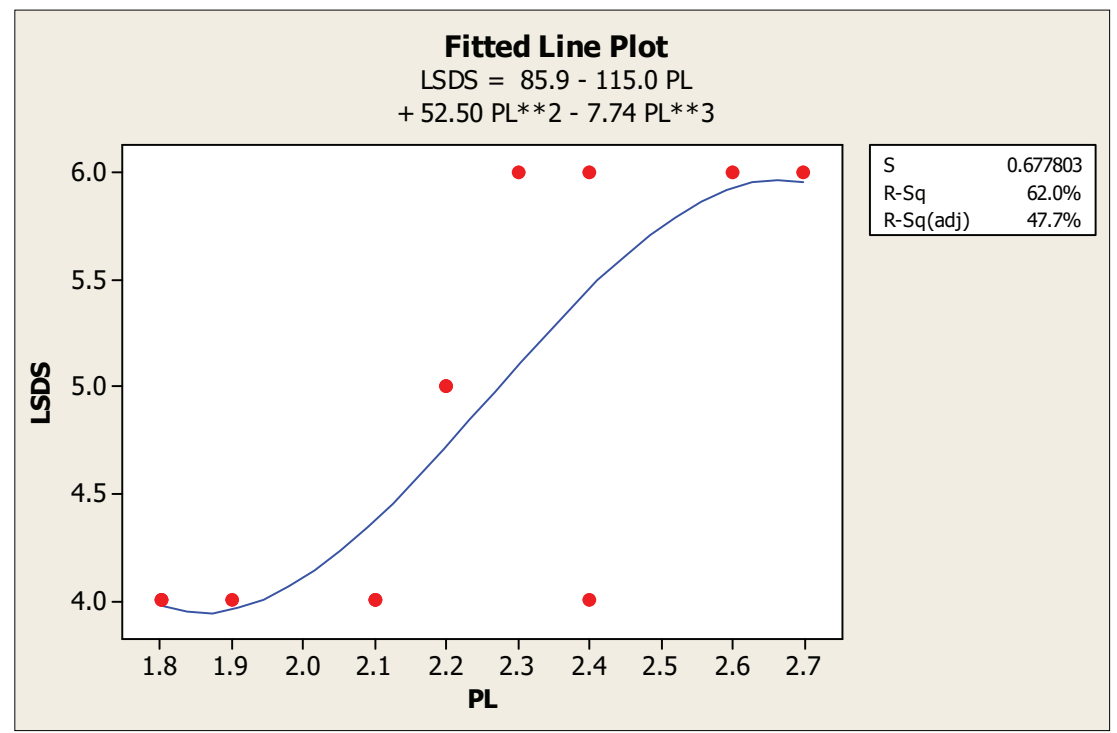

Figure 8: Polynomial regression analysis between leaf spot disease severity (LSDS) and petiole length (PL) of the accessions belonging to cluster 2

\section{CONCLUSION}

This study confirmed that the leaf spot disease is widely distributed in major cinnamon growing areas, whereas rough bark disease severity is still at the initial stage of spreading. The current study further confirms that leaf morphology is not directly linked to both leaf spot and rough bark disease severities in the representative accessions from major cinnamon growing areas in Sri Lanka. The developed disease assessment keys would be helpful for assessing leaf spot and rough bark disease severities in the future. According to the study, early detection of pathogens and control measures of leaf spot and rough bark diseases should be adopted to minimise further spread of the diseases, to prevent economic losses and to increase the productivity of cinnamon.

\section{Acknowledgement}

The authors acknowledge financial support from the TURIS grant (RU/TURIS/PhD/03) of University of Ruhuna to carry out the study. The authors are thankful to Mrs Sheron Weerasooriya and former Director, Mr K.G.G. Wijesingha of the Cinnamon Research and Training Institute, Palolpitiya. 


\section{REFERENCES}

Abeysinghe P.D., Wijesinghe K.G.G., Tachida H. \& Yoshda T. (2009). Molecular characterization of cinnamon (Cinnamomum verum Presl.) accessions and evaluation of genetic relatedness of cinnamon species in Sri Lanka based on $\operatorname{Trn} \mathrm{L}$ intron region, intergenic spacer between $\operatorname{trn} \mathrm{T}-\operatorname{trn} \mathrm{L}$, $\operatorname{trn} \mathrm{L}-\operatorname{trn} \mathrm{F}, \operatorname{trn} \mathrm{H}-p s b \mathrm{~A}$ and nuclear ITS. Research Journal of Agriculture and Biological Sciences 5(6): 1079-1088.

Anandaraj M. \& Devasahayam S. (2004). Pests and diseases of cinnamon and cassia. In: Cinnamon and Cassia (eds. P.N. Ravindran, K.N. Babu \& M. Shylajah), pp. 239-258. CRC Press, New York, USA.

DOI: https://doi.org/10.1201/9780203590874

Azad R., Senanayake G., Wasantha Kumara K.L., Ranawaka R.A.A.K., Pushpakumara D.K.N.G., Wijesinghe K.G.G. \& Geekiyanage S. (2015). Morphological variation within progeny and deviations from mother plant reveal the allele richness in Cinnamomum verum germplasm: a case study from Deiyandara; Matara collection at the early vegetative stage. Journal of Tropical Agricultural Research and Extension 18(4):163-167.

Azad R., Ranawaka R.A.A.K., Senanayake G., Kumara K.L.W., Wijesinghe K.G.G., Pushpakumara D.K.N.G \& Geekiyanage S. (2016). Morphological variation of cinnamon (Cinnamomum verum Persl.) germplasm in Matara District of Sri Lanka. International Journal of Minor Fruits, Medicinal and Aromatic Plants 2(1): 6-14.

Azad R., Wasantha Kumara K.L, Senanayake G., Ranawake R.A.A.K., Pushpakumara D.K.N.G. \& Geekiyanage S. (2018). Flower morphological diversity of cinnamon (Cinnamomum verum Persl) in Matara district, Sri Lanka. Open Agriculture 3(1): 236-244.

DOI: https://doi.org/10.1515/opag-2018-0025

Burdon J.J. (1987). Diseases and Plant Population Biology. Cambridge University Press Archive.

Davis R.D., Irwin J.A.G. \& Cameron D.F. (1984). Variation in virulence and pathogenic specialization of Colletotrichum gloeosporioides isolates from Stylosanthes scabra cvv. Fitzroy and Seca. Crop and Pasture Science 35(5): 653662.

DOI: http://dx.doi.org/10.1071/AR9840653.

Department of Export Agriculture, Sri Lanka (2013). Cinnamon. Available at http://www.exportagridept. gov.lk/web/index. php? option $=$ com_content \&view $=$ article \&id $=128 \& I t e m-$ $i d=159$ \&lang=en, Accessed 8 June 2018.

Fu C.H. \& Chang T.T. (1999). Anthracnose of cinnamon. Taiwan Journal of Forest Science 14: 513-515.

Guillaumin J.J., Mohammed C., Anselmi N., Courtecuisse R., Gregory S.C., Holdenrieder O. \& Rishbeth J. (1993). Geographical distribution and ecology of the Armillaria species in Western Europe. European Journal of Forest Pathology 23(6-7): 321-341.
Henn J.J. et al. (13 authors) (2018). Intraspecific trait variation and phenotypic plasticity mediate alpine plants species response to climate change. Frontiers in Plant Science 9:1548-1560.

DOI: https://doi.org/10.3389/fpls.2018.01548

Jayasinghe G., Kumara K.W. \& Wijayawardana M. (2017). Rough bark disease on cinnamon (Cinnamomum zeylanicum): disease symptoms development and the causal agent with special reference to its morphology, histopathology and nutritional status of affected plants. Proceedings of the Symposium on Minor Export Crops (ed. B. Marambe), pp. 16 - 17 March, Peradeniya, Sri Lanka.

Karunakaran P. \& Nair M.C. (1980). Leaf spot and dieback disease of Cinnamomum zeylanicum caused by Colletotrichum gloeosporioides. Plant Disease 64(2): 220-221.

DOI: http://dx.doi.org/10.1094/PD-64-220.

Kumara K.L.W. (1999). Effect of some agronomic practices on the incidence of leaf spot disease (Colletotrichum gloeosporioides) in cinnamon (Cinnamomum zeylanicum Blume) in southern region of Sri Lanka. SLAASUniversity of Ruhuna Seminar on "Pest control in the next millennium", SLAAS, Colombo.

Lamari L. (2008). Assess 2.0 Image Analysis Software for Disease Quantification, pp. 1-125. American Phytopathological Society, Saint Paul, USA. DOI: https://doi.org/10.1094/AssessHelp

Mabberley D.J. (2008). Mabberley's Plant Book: a Portable Dictionary of Plants, their Classifications and Uses, $3^{\text {rd }}$ edition. Cambridge University Press, Cambridge, UK.

Minitab-14 (2003). Statistical software for windows. Minitab Inc., State College, USA.

Prakasam V. (1991). Red leaf spot of cinnamon in Lower Pulney hills of Tamil Nadu. Indian Cocoa, Arecanut and Spices Journal 14(3): 123.

Rajapakse R. \& Kumara K.L.W. (2007). A review of identification and management of pests and diseases of Cinnamon (Cinnamomum zeylanicum Blume). Tropical Agricultural Research and Extension 10: 1-10. DOI : https://doi.org/10.4038/tare.v10i0.1864

Ristaino J.B. \& Gumpertz M.L. (2000). New frontiers in the study of dispersal and spatial analysis of epidemics caused by species in the genus Phytophthora. Annual Review of Phytopathology 38(1): 541-576.

DOI: http://dx.doi.org/10.1146/annurev.phyto.38.1.541.

Sri Lanka Customs (2016). Sri Lanka Customs Annual Performance Report 2016. Sri Lanka Customs.

Team of TURIS 2013 Project (2016). Descriptors for Cinnamon (Cinnamomum verum). University of Ruhuna, Sri Lanka.

Wijesinghe K.G.G. \& Gunarathna W.D.L. (2001) Characterization of true cinnamon (Cinnamomum verum Persl) based on leaf morphology and their relationship with yield and quality. Proceedings of the $57^{\text {th }}$ Annual Sessions of the Sri Lanka Association for the Advancement of Science, part I, p. 42. 